\title{
Are SHGs catalysts for rural empowerment? Impact assessment of Stree Shakti interventions in India
}

\author{
Vanishri R. Hundekar \\ KLS Gogte Institute of Technology, \\ Belagavi, Karnataka, India \\ Email: vanirhj9@gmail.com
}

\begin{abstract}
Self-Help Group (SHG) is a crucial initiative to enable financial inclusion with multiple aims like access to microcredit, enabling income generation, savings and thereby eventually empowering the poor. This study attempts to evaluate if SHGs can be a change agent influencing women's empowerment. Findings revealed that there is an increase in the average income, and savings of SHG members. Microfinance related loan augment was found to be causing a significant difference in their empowerment level. Social and legal awareness caused a considerable impact on the social empowerment of members and better access to credit facilities has the significant impact on their economic empowerment followed by access to resources and promotional assistance. While study for longer term effect is desirable, even in the short term the program helped to improve the consumption and income generation. SHG program could well be the catalyst to achieve inclusive growth. The study offers important policy suggestions.
\end{abstract}

Keywords: SHG; self-help group; women empowerment; financial inclusion; income generation; microcredit and micro savings; rural women; microfinance; Stree Shakti program.

Reference to this paper should be made as follows: Hundekar, V.R. (2020) 'Are SHGs catalysts for rural empowerment? Impact assessment of Stree Shakti interventions in India', Int. J. Financial Services Management, Vol. 10, No. 1, pp.77-97.

Biographical notes: Vanishri R. Hundekar is a Faculty of Finance in KLS Gogte Institute of Technology, Belagavi, Karnataka. She has presented research papers in national and international conferences and published research papers in reputed journals. She has also been awarded as Best Researcher in Finance area at ICBM-AMP academic excellence award Hyderabad. Her area of interest includes microfinance, financial inclusion, bank linkage program, banking and finance.

\section{Introduction}

Indian economy is recognised to be one of the fastest-growing economies in the world. Indian economic development lies in the prosperity of its villages as the hinterlands in India consist of about 650,000 villages as $68.84 \%$ of its population lives there (Census of India, 2011). However, a significant proportion of its villages do not have a banking outlet to boast of, leaving swathes of the rural populace in financial exclusion. Microfinance initiative has been instrumental in achieving inclusive growth for many 
economies around the world including India per se. Financial inclusion is a novel exemplary model for economic growth which assumes an essential role in mitigating poverty level. The marginalised section of the society is commonly not covered under the formal financial framework owing to the high cost associated with small scale financial services. Inaccessibility to formal financial services and the excessive terms of informal credit for the marginalised section of the society creates a robust need and generous scope for cost-effective approaches to serve the financial needs of the poor households. In a developing country like India, it becomes paramount to cater to the financial demands of poor households; this could make the economy less vulnerable. As a step towards bringing financially excluded sections of the society under a formal financial system, National Bank for Agriculture \& Rural Development (NABARD) as an official body-initiated people friendly scheme of organising them in Self-Help Groups and linking such SHGs with banks, in the year 1992. The main aim of this program is to augment the resources to deprived section by facilitating financial access through the formal financial channel. Shri Arun Jaitley, former Finance Minister in his address mentioned that initiative of NABARD led SHG, has reached the milestone of 25 years' timeline. The program was officially launched in the year 1992, with a target of linking 500 SHG in a year and has now transformed into the world's largest microfinance program. The domain of SHG consists of $85.4 \%$ (NABARD Report) of the women's groups and is the mainstay program for the empowerment of rural poor in the country. SHG model is considered to be the most flourishing, beneficial and widely acknowledged model among the marginalised section in India. Today, in India, SHGs epitomise a unique approach to financial intermediation, which aims to give access to low-cost financial services with a process of self-management and empowerment of SHG members.

\subsection{An introduction to Stree Shakti scheme}

Stree Shakti scheme is one such intervention introduced by the Government in the state of Karnataka. The program was launched during 2000-2001 and it is being implemented throughout the state of Karnataka to empower women and make them self-reliant. Stree Shakti is channelised through the formation of SHGs as a savers group with some saving targets. Every group has to save a small amount per month. This saved amount of money is deposited in a bank. The bank where savings are deposited by SHG, examine the performance of the group periodically, and if the performance is found to be good, the group gets credit facilities by the bank, without any collateral. The main aim of the Stree Shakti scheme is to inculcate the saving habits among beneficiaries and empower them economically. About 10-15 members falling below the poverty line or landless agricultural labourers join together to form a group. And these groups are formed and monitored by Anganwadi Workers and Taluk federations.

\subsection{Intervention programs of Stree Shakti scheme}

Since its inception in 2000, the Stree Shakti program has introduced several strategic initiatives for inclusive rural growth and development. The program provides microfinance at the grass-root level to the rural poor through the SHG bank linkage program without any collateral. Under this program the beneficiaries of SHG are provided a $6 \%$ interest subsidy for the bank loan along with revolving fund facilities. 
Stree Shakti program emphasises the training and development activities of Anganwadi workers and SHG members. The program also endeavours to empower them by providing capacity building and vocational skills in training, handicraft, etc. The main objective of the program is to encourage skill-based economic activities at the grass-root level. It emphasises providing a platform to market the products produced by SHG members by organising annual exhibitions and marketing activities. Incentives are given to the groups with excess savings and for undertaking income-generating activities.

The major objective of the Stree Shakti scheme is to enable an environment conducive for the economic development of women. The scheme was channelised through the SHG bank linkage program which would provide opportunities for saving, accessibility to credit facilities and eventually facilitate in undertaking income-generating activities. Without socio-economic empowerment at the grass-root level consisting of the underprivileged and weaker section of the society, holistic development of economy does not happen and the very purpose of Microfinance is to empower weaker sections of the society. In the context of this, an attempt has been made in this research study to empirically examine whether participation in Stree Shakti enabled SHG leads to the socio-economic empowerment of the members.

\subsection{Research objectives}

The present study is an attempt to investigate the impact of the Stree Shakti scheme on the empowerment of rural women. As the objective of the Stree Shakti scheme is to enable an environment conducive for the economic development of women (Naganagoud, 2012). The study is trying to examine the socio-economic conditions of members' pre and post participation in the Stree Shakti program. The study is trying to investigate the impact of Stree Shakti's model on Social Empowerment and Economic Empowerment of members.

The findings of the study will be of immense use to the financial institutions and the policymakers by understanding the regional imbalances in terms of financial inclusion through microfinance and to get a better perspective of the trials and problems faced by the marginalised section of the society

\subsection{Scope and significance of the study}

The study is undertaken in Belagavi, Karnataka. Primary data is collected from SHG members using a structured questionnaire to determine whether and to what extent participation in Stree Shakti program has an impact on the socio-economic empowerment of its members in the selected region; it is one of the 30 districts of Karnataka. Under the Stree Shakti scheme, Department of Women and Child Development has launched the SHG program on October 18, 2000, in the District.

\section{Literature review}

\subsection{Empowerment through self-help groups}

As per UNIFEM (2000), empowerment comprises of "ganging the capacity to create decisions and exercise, building up a feeling of self-esteem, faith in one's capacity to tie 
down wanted changes and the privilege to control one's life." Empowerment infers a development of benefits and abilities of individuals to impact the control and consider Accountable on which influences their lives (World Bank Resource book). In India from Fifth Five Year Plan onwards, there has been a checked move in the way to deal with the issues from welfare to improvement and empowerment of women, the legislature of India proclaimed 2001 as Women's Empowerment Year.

Women's empowerment and economic advancement are firmly interrelated. While improvement itself will achieve women empowerment, enabling them to realise changes in basic leadership, which will directly affect economic advancement (Duflo, 2012).

Das and Bhowal (2013) attempted to understand the dimension of SHGs as an empowerment model or financial model by using statistical tools like correlation and ANOVA. The study revealed that participants in the overall score of variables on empowerment were essentially more than the overall score of variables on the financial model.

Empowerment of women includes higher literacy level and education, better awareness about healthcare, equal ownership of productive resources and participation in economic and commercial activities, improved standard of living and self-reliance of women. State and Central governments have formulated and implemented several schemes for the social and economic development of rural women, but the results don't witness the overall empowerment of women in rural areas. Though the women have indicated a considerable level of empowerment after joining SHG, Officials of Women and Child development found the performance of Government-sponsored Stree Shakti SHG as minimal as 51\% (Yatnall et al., 2012). Overall SHGs have a positive effect on the economic, social and political empowerment level of members (Brody et al., 2017).

\subsection{Development of study hypothesis}

Socio-economic factors of rural people changed after joining SHG with Special Reference to Mettupalayam Taluk in Coimbatore District, and also economic activities of women members are proven to be successful (Thangamani and Muthuselvi, 2013). SHGs have provided numerous financial advantage in terms of increased assets, enhanced savings and borrowing practices, increased income and employment and improved social life of rural households (Vachya and Kamaiah, 2015).

A research conducted by Poominathan et al. (2016) stated that among other variables such as age, education, women empowerment is highly influenced by the income level of members.

Datta (2015) mentioned that SHG has brought some noticeable changes in a variety of dimensions in the lives of the socially and economically marginalised section in Bihar. A substantial percentage of households are freed up from high-cost debt.

The participatory approach of the SHG model is helping rural women to have a favourable attitude towards the SHG model because SHG helped them to reduce their financial dependence on informal money lenders in rural areas. They could access hasslefree bank loans after joining SHG, which in turn helps them to increase their income level (Patil and Kokate, 2017). Bammi (2014) mentioned that the bank linkage program seems to impact positively on the lives of the rural section in the form of increased savings, improved standard of living.

The efficacy of SHGs on women's economic empowerment can be measured through the change in income and savings levels. And it was examined by the author by 
evaluating an increase in the revenue, level of jobs and improvement in savings before and after entering the SHG program. The research found that SHGs have an enormous impact on women's empowerment and socio-economic development of rural individuals (Sarania, 2015).

H1: Participation in SHG is effective in improving the status of the members in terms of income, savings, and expenditure and debt level.

\subsection{Economic empowerment}

Several studies by the various researchers led to perceive the connection between participation in self-help groups and economic empowerment. In a study done by Pillai and Abraham (2017), the authors mentioned SHG can be viewed as a cost-effective, scalable, and sustainable tool for financial inclusion in India.

Mohaptra and Sahu (2016) attempted to analyse individual, household and environmental factors that influence participation in SHGBLP, a composite index of women empowerment is analysed considering three dimensions viz. autonomy, economic empowerment, and the gender relationship. The study discovered that the socio-economic and environmental factors influence the participation in SHG programs. And landholding, mean asset value and per capita household income have a positive impact on participation in the program.

Swamy (2014) stated that women use resources in such a way that contributes significantly to their savings and household income, these increases attribute to the decision making the ability of women.

Sandhya and Ranjini (2018) researched SHG members working in manufacturing and production sectors in Mysuru District, the findings indicate that the majority of the beneficiaries have used the loans for starting their part-time micro-enterprises which is supplementing their wages they are getting from the factory. This has enabled the members of SHG to become economically independent and helped them earn a stable income.

The inter-lending system practised in the SHG enables members to borrow the loan to supplement their income without depending on any external financial sources helping them to create additional income. This eventually increases their bargaining power within their household and leads to empowerment. Economic factors have the most significant impact on empowering rural women (Swain and Wallentin, 2012).

H2: Participation in Stree Shakti launched SHG has a significant impact on the economic empowerment level of members

\subsection{Social empowerment}

In addition to the economic gains, the SHG program has endowed some other social benefits among rural women like increased social communication, increased awareness and understanding about formal banking systems which have positive effects on the empowerment of rural women (Rajeev et al., 2019). Patil and Kokate (2017) investigated the attitudinal aspect of members of SHG using factor analysis. The investigation recognised seven prime components viz. coping up ability', 'personality traits', 'resource utilisation and building', 'entrepreneurial attributes', 'organisational governance', 'financial inclusion' and 'economic upliftment' in charge of positive disposition. 
Gangadhar and Malyadri (2015) ascertained the indicators of empowerment of SHG members. The study discovered that microfinance is an effective tool in improving the women empowerment level, and there has been a steady improvement in household economic decision making, legal awareness, mobility, economic security.

Mohan (2011) revealed that microfinance was instrumental in bringing psychological and social empowerment in terms of skill development, increased self-esteem, than economic empowerment.

Desai and Olofsgård (2019) while attempting to examine the improvement in the use of public goods have used SHG intervention. The study revealed that SHG members possess greater knowledge of how to address problems of road, health service, and water supply. They are more likely to contact government authorities regarding their grievances about public goods. The presence of SHG has promoted cooperation among women members.

Kumar et al. (2019) investigated the link between SHG membership and political awareness, and utilisation of initiatives of government schemes. Findings showed a positive relationship of SHG enrolment with a few political cooperation pointers, additionally, members are more aware of the welfare scheme and they are more likely to utilise these schemes indicating that they are able to use the information put it into action either because of their empowerment or group empowerment. The effectiveness of the microfinance system depends not just on the amount of groups created, but also on the survival and sustainability of such groups (Das and Guha, 2019).

H3: Awareness level of members has a significant impact on social empowerment of members

\subsection{Conceptual framework of the study}

Figure 1 Model of empowerment through SHG

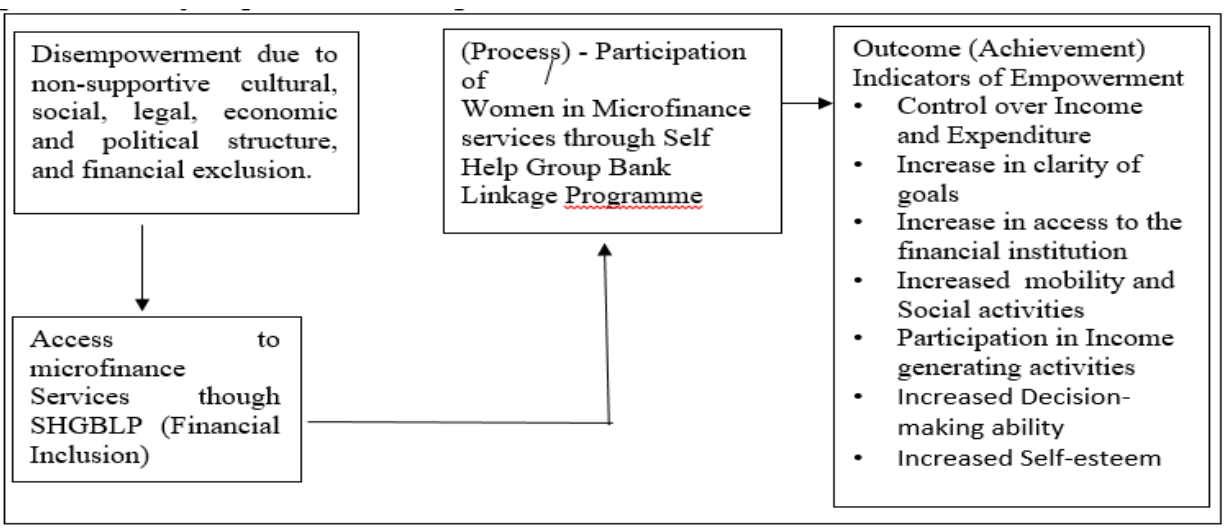


Figure 2 Conceptual model

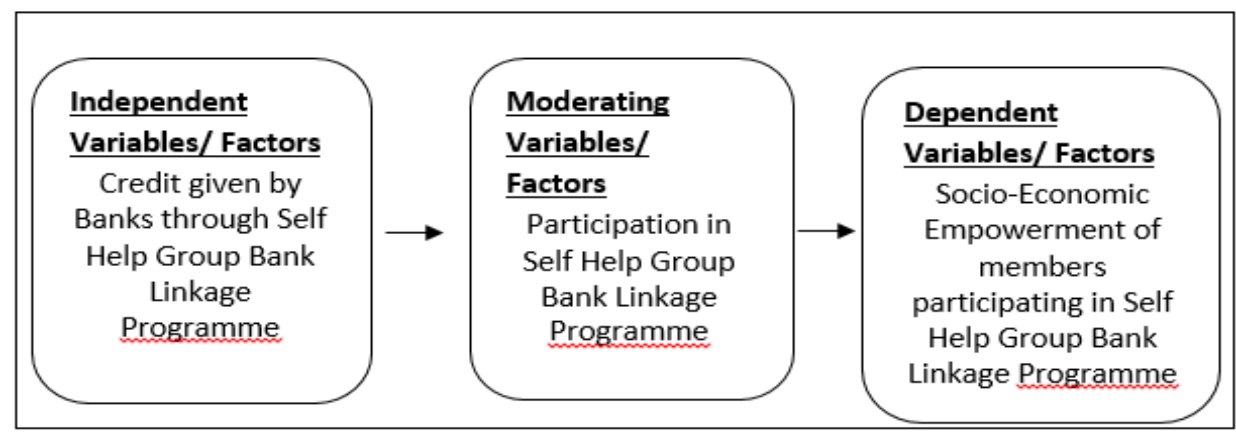

\section{Research methodology}

The present study is descriptive and empirical in nature. This research study aims to find out whether Stree Shakti launched SHGs can transform the socioeconomic status of beneficiaries and impact their empowerment level. Questionnaires were administered on the members of SHG of Belagavi. The necessary information is collected from members of matured SHG's (exist at least in the last 3 years) promoted by Stree Shakti from District Wise Report on SHG Group (2018). Further, to analyse the empowerment level, the respondents were interviewed and Random Sampling Method is used to select the respondents. Statistical tests used: Validity Test, Descriptive Statistics, Paired-t-test, and Regression analysis.

\subsection{Developing data collection instrument}

The research tool consisted of a structured questionnaire with a variety of response formats like ranking, multiple choices, and Likert scale are used. Part I of the questionnaire was designed to elicit the demographic information related to members. Part II of the questionnaire was designed to know the participation of members in SHG activities, and Part III of the questionnaire was designed to know the transition brought by SHG in terms of empowerment of members, Part IV was designed to know the status of members before and after participation in SHG.

\subsection{Determination of sample size}

Karnataka has been forefront in providing rural banking services and occupies the third position in promoting SHG after Andhra Pradesh and Tamil Nadu. And credit linkage of SHG with banks is the third highest in Karnataka (47.78\%) (NABARD Report, 2019). Referring to the data of branch banking statistics published by RBI and Gram Panchayat i.e. District Talukwise number of functioning SHG in 2018, 1200 groups are functioning in Belagavi, Karnataka. The group administration approach was used to distribute 250 
questionnaires among the target population. A total of 198 duly filled questionnaires were returned. Out of 198, 34 questionnaires were erroneous having incomplete data, among 164 respondents 40 members discontinued the membership in SHG under the Stree shakti scheme. For validity purposes using a $10 \%$ rule of sampling were collected for analysis. Four Questionnaires were excluded for rounding off. Therefore for further analysis, 120 responses were selected under Stree Shakti launched SHGs.

\subsection{Research questions and hypothesis}

\subsubsection{Research questions}

Research question 1: Whether participation in SHGBLP is effective in improving the status of the members. Here, improvement in status is assessed based on the change in the Income level, expenditure level, and Savings and Debt level of the members after participation in SHG.

Research question 2: Whether participation in SHG has an impact on the social empowerment level of members, such as (a) Increased self-confidence; (b) Improved decision-making skills;(c) Leadership quality;(d) Active participation in community developmental activities (e) Better communication skills.

Research question 3: Whether participation in SHGBLP has an impact on the economic empowerment level of members, such as (a) Increased standard of living; (b) Increased monthly income and savings; (c) Possession of assets;(d) Better control over earnings (e) Able to contribute towards the family income.

\subsubsection{Hypothesis}

Research question 1 is addressed by hypothesis (H1): Participation in SHG is effective in improving the status of the members.

A paired-t-test is used to know the status of members before and after participation in SHG. Here improved status is assessed based on the change in the variables such as Income level, expenditure level, Savings and the Debt level of the members after participation in SHG. The data collected is comparative and collected using the Likert scale, each item is tested comparatively (before and after participation in $S H G$ ).

Research question 2 is addressed by hypothesis (H2): Awareness level has impacted the social empowerment of members.

Multiple regression analysis is used to ascertain the impact of independent variable i.e. awareness level and was correlated with each dependent variable of Social empowerment which includes data about (a) Increased self-confidence; (b) Improved decision-making skills;(c) Leadership quality;(d) Active participation in community developmental activities (f) Better communication skills and overall variance was tested.

Research question 3 is addressed by hypothesis (H3): Participation in Stree Shakti launched SHG has an impact on the Economic empowerment level of members. 
To test this hypothesis, Multi-Regression analysis is used for impact evaluation, to ascertain the impact of independent variable i.e. Participation in SHG and was correlated with each dependent variable of Economic empowerment which includes data about (a) Increased standard of living; (b) increased monthly income and savings; (c) Possession of assets;(d) Better control over earnings (e) Able to contribute towards family income and overall variance was tested.

\section{Analysis and interpretation of data}

\subsection{Demographic profile of the respondents}

Table 1 Demographic profile of the respondents

\begin{tabular}{lccc}
\hline \multirow{2}{*}{ Demographic variables } & Category & \multicolumn{2}{c}{ Statistics } \\
\cline { 2 - 4 } & Less than 20 & Frequency & Percentage \\
\hline \multirow{4}{*}{ Age } & $20-25$ years & 24 & 10.0 \\
& $25-30$ years & 20 & 20.0 \\
& $30-35$ years & 32 & 16.7 \\
& 35-40 years & 16 & 26.7 \\
Type of family & 40 years and above & 16 & 13.3 \\
& Nuclear & 64 & 13.3 \\
\multirow{3}{*}{ Education } & Joint & 56 & 53.3 \\
& Illiterate & 8 & 46.7 \\
\hline \multirow{2}{*}{ Occupation } & Primary school & 68 & 6.7 \\
& High school & 44 & 56.7 \\
& Agricultural labour & 44 & 36.7 \\
\hline
\end{tabular}

\subsection{Participation in Stree Shakti program is effective in improving the status of the members}

The objective is to know whether the participation in SHGBLP is instrumental in improving the status of the members. Here, improved status is assessed based on the change in the variables such as Income and expenditure level, Savings and the Debt level of the members after participation in SHGBLP. Paired-' $t$ '-test is applied to compare two population means where two samples are studied in which observations in one sample can be paired with observations in the other sample. The $T$-test compares the actual difference between the two means in relation to the variation in the data expressed in terms of standard deviation. The test is widely used to see if the observed difference between two means is statistically significant. 
Table 2 Reliability analysis for items in the questionnaire

\begin{tabular}{ccc}
\hline \multicolumn{3}{c}{ Reliability statistics } \\
\hline Cronbach's alpha & Cronbach's alpha based on standardised items & No. of items \\
\hline .683 & .650 & 5 \\
\hline
\end{tabular}

A paired-t-test on monthly income before and after joining SHGs

Hypothesis $1.1_{0}$ - There is no significant change in the income level

Hypothesis $1.1_{a}$ - There is a significant change in the income level

Inference: Since the probability, value is $0.000(p<0.05)$, the null hypothesis is rejected and it can be concluded that there is a significant change in the monthly income before and after joining the SHGBLP. The mean score of income after joining (3.47) is more than (2.97). Thus, the participation in SHGBLP has a significant impact on the income level of the respondents.

A paired-t-test on monthly expenditure before and after joining SHGs

Hypothesis $1.2_{0}$ - There is no significant change in the expenditure level

Hypothesis $1.2_{a}$ - There is a significant change in the expenditure level

Inference: Since the probability, value is $0.001(p<0.05)$, the null hypothesis is rejected and it can be concluded that there is a considerable change in the monthly Expenditure before and after joining the SHGs. The mean score of expenditure after joining (2.18) is higher than (1.93). The expenditure level after joining SHG has significantly increased.

A paired-t-test on monthly savings before and after joining SHGS

Hypothesis $1.3_{0}$ - There is no significant change in the savings

Hypothesis $1.3_{a}$ - There is a significant change in the savings

Inference: Since the probability value is $0.096(p>0.05)$, the null hypothesis is accepted and it can be concluded that there is no considerable change in the monthly savings after joining SHG.

A paired-t-test on monthly debt level before and after joining SHGs

Hypothesis $1.4_{0}$ - There is no significant change in the debt level

Hypothesis $1.4_{a}$ - There is a significant change in the debt level 
Are SHGs catalysts for rural empowerment?

Table 3 Paired sample test of value of monthly income

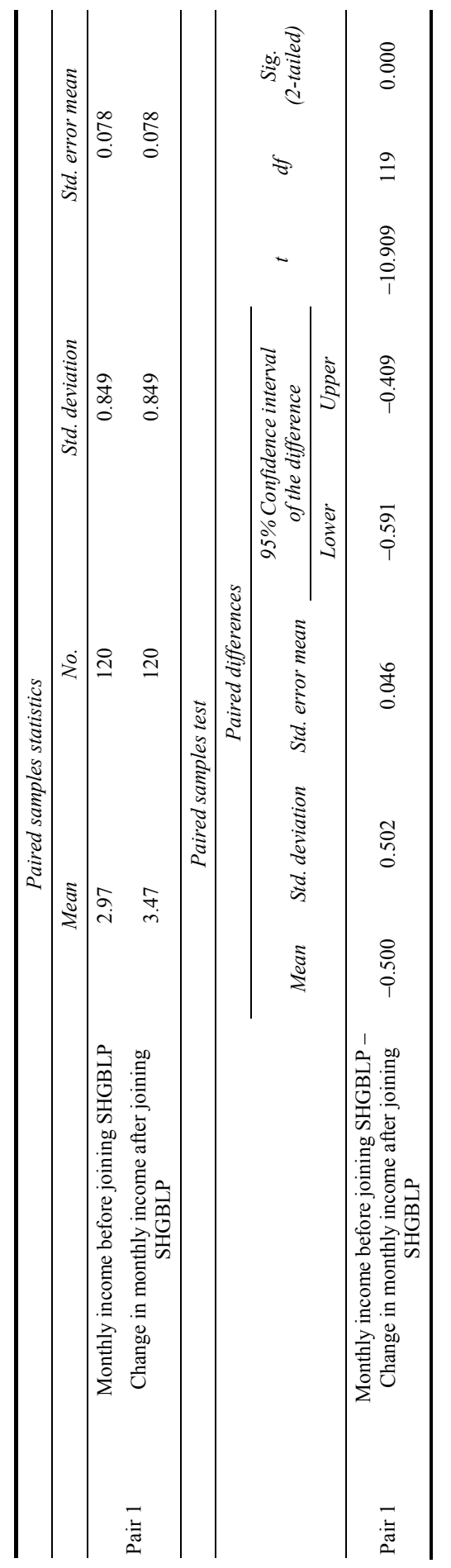


Table 4 Paired sample test of value of monthly expenditure

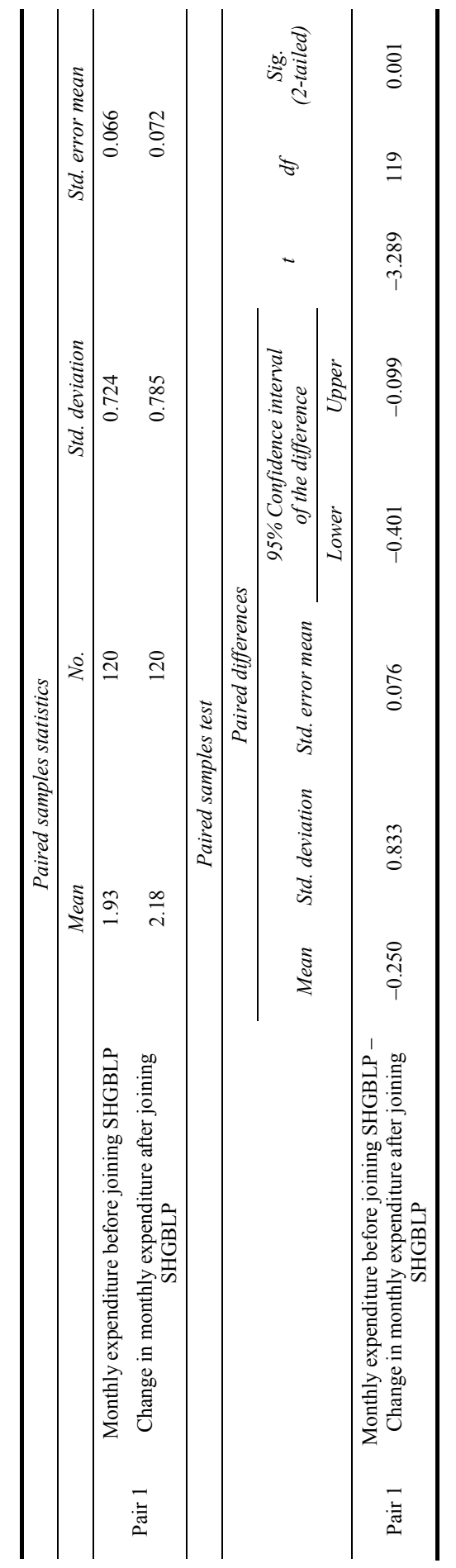


Are SHGs catalysts for rural empowerment?

Table 5 Paired sample test for values of monthly savings

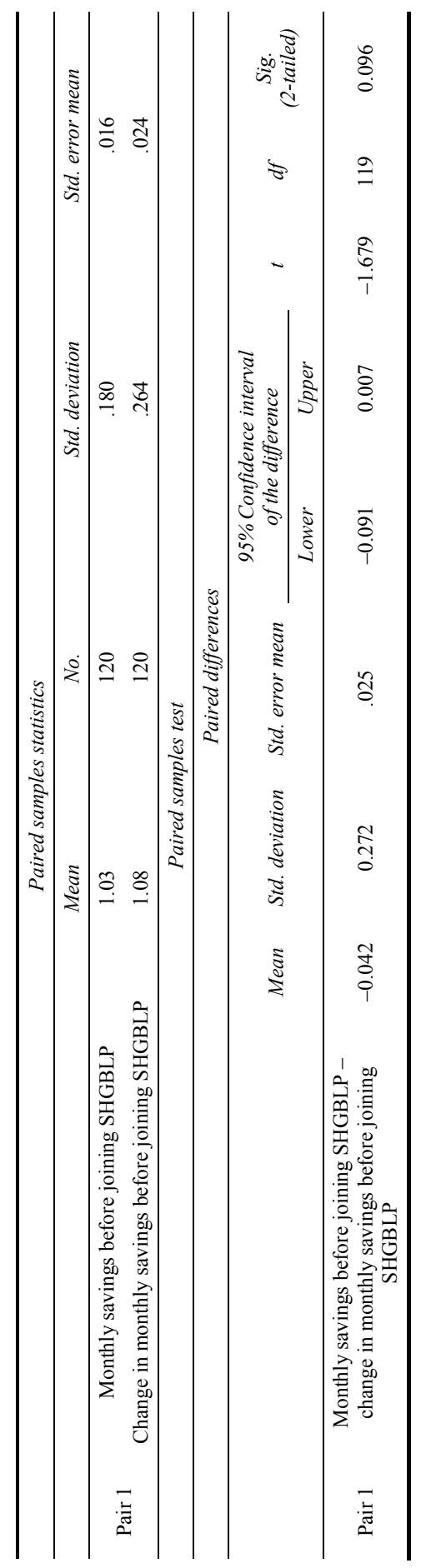


Table 6 Paired sample test for values of debt level

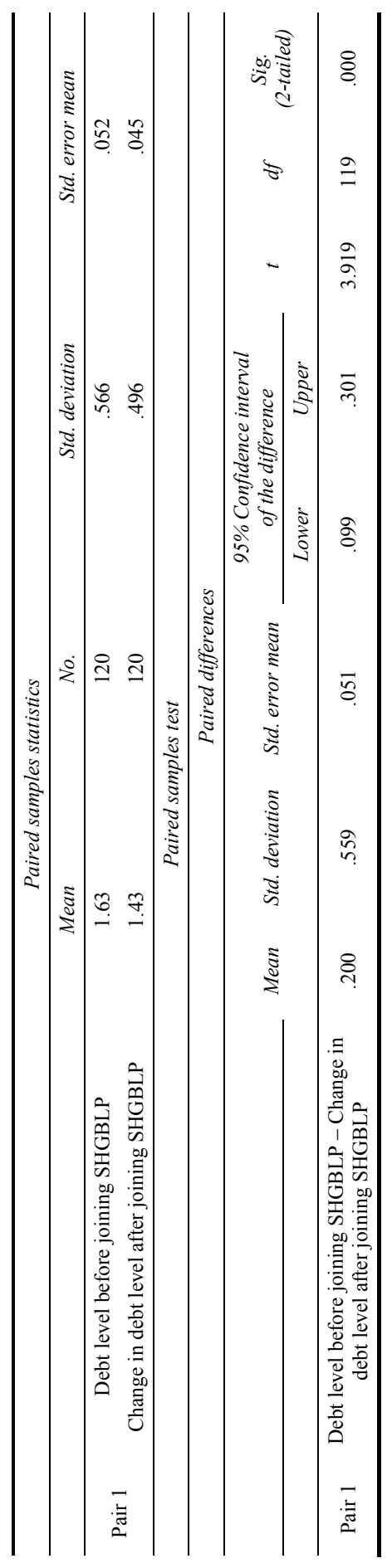


Inference: Since the probability value is $0.000(p<0.05)$, the null hypothesis is rejected and it can be concluded that there is a considerable change in the monthly Debt level before and after joining the SHGs. Thus the participation in SHGBLP has reduced the debt level of the respondents.

\subsection{Impact assessment of Stree Shakti scheme on empowerment}

Table $7 \quad$ Reliability statistics

\begin{tabular}{cc}
\hline \multicolumn{2}{c}{ Reliability statistics } \\
\hline Cronbach's alpha & No. of items \\
\hline .083 & 4 \\
\hline
\end{tabular}

Hypothesis 2.10 - Awareness level has no impact on social empowerment of SHG members

Hypothesis 2.1 a - Awareness level has an impact on social empowerment of SHG members

The objective of testing this hypothesis is to know whether the awareness level has an impact or causes any variance on Social Empowerment. This helps to understand, how the awareness level and each of its dimensions, i.e. awareness about Government programs and schemes, Banking facilities and transactions, Availability of local resources, Social and legal awareness are related to and cause impact (variance) on Social Empowerment of members. Multiple regression analysis was needed to be employed here because the independent variables (Awareness level) were all measured on continuous scales and even the dependent variable Social Empowerment was measured on a continuous scale.

Interpretation: Multiple regression analysis was conducted to determine how dimensions of awareness level were related to dimensions of Social empowerment of members. This overall regression model produced an $R^{2}$ of .163 which means that the awareness level has $16 \%$ of the variance on the dependent variable Social Empowerment. The overall model was significant $(4119)=5.583 p<.005$ and it accounted for $16 \%$ of the variance. It is found that Social and legal awareness $(\beta=.407, t=3.077, p=0.003)$ has the highest significance or impact on social empowerment of members followed by awareness about banking facilities and transaction $(\beta=.240)$ and awareness about Govt. programs and schemes $(\beta=.180)$. Availability of local resources is not having a considerable influence on the social empowerment of members.

\section{Inference:}

Null hypothesis $H_{0}$ is rejected, Since $p(0.000)<0.005$, hence awareness level has an impact on Social empowerment of members.

D Awareness level showed a variance of $16 \%\left(R^{2}\right.$-value) on the Social Empowerment of members.

Hypothesis 3.1 - Participation in Stree Shakti launched SHG has no impact on the Economic Empowerment of participants

Hypothesis 3.1 - Participation in Stree Shakti launched SHG has an impact on Economic Empowerment of participants 
Table 8 Results of multiple regression between SHG program and social empowerment

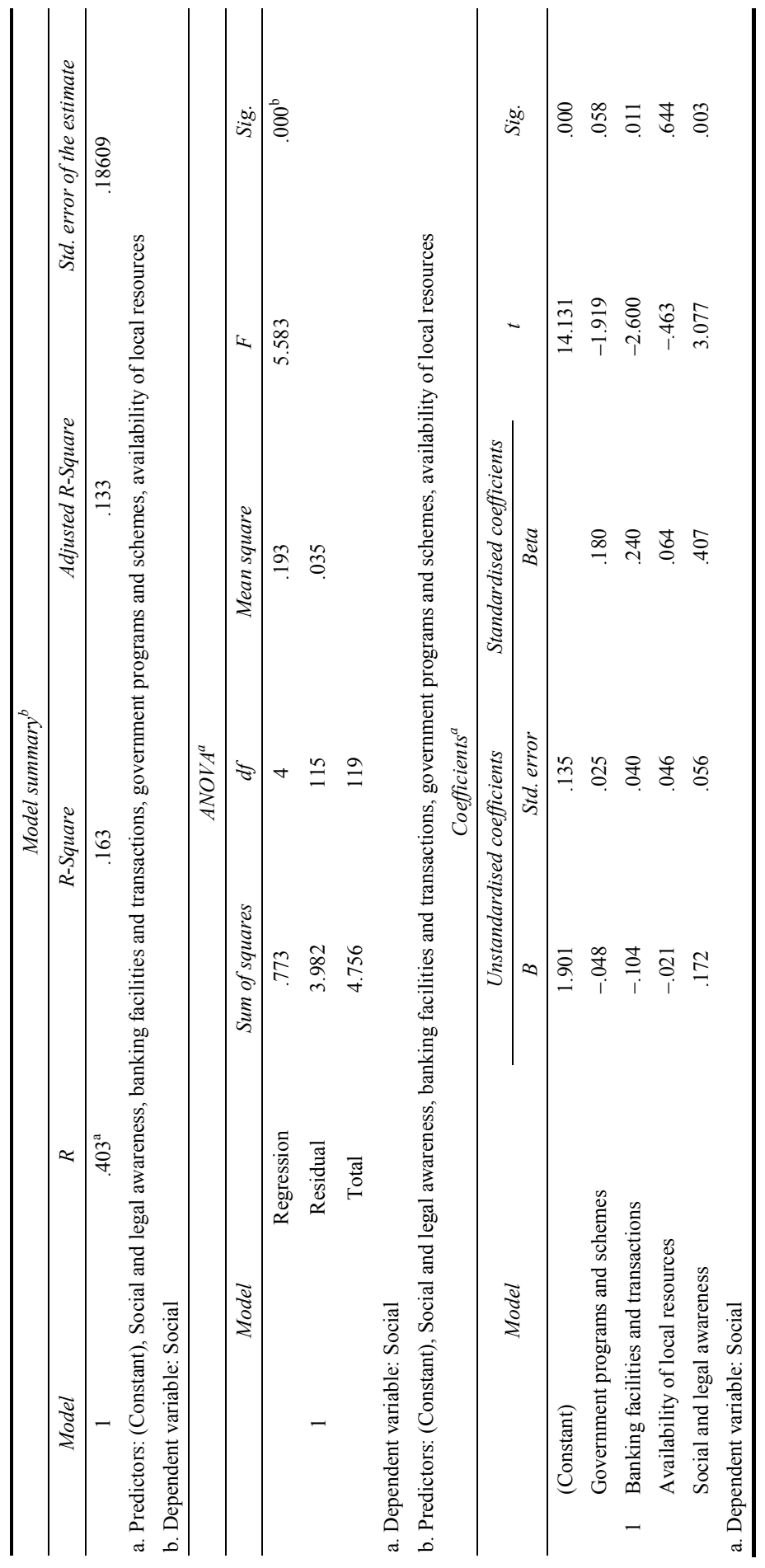


Table 9 Results of multiple regression between SHG program and economic empowerment

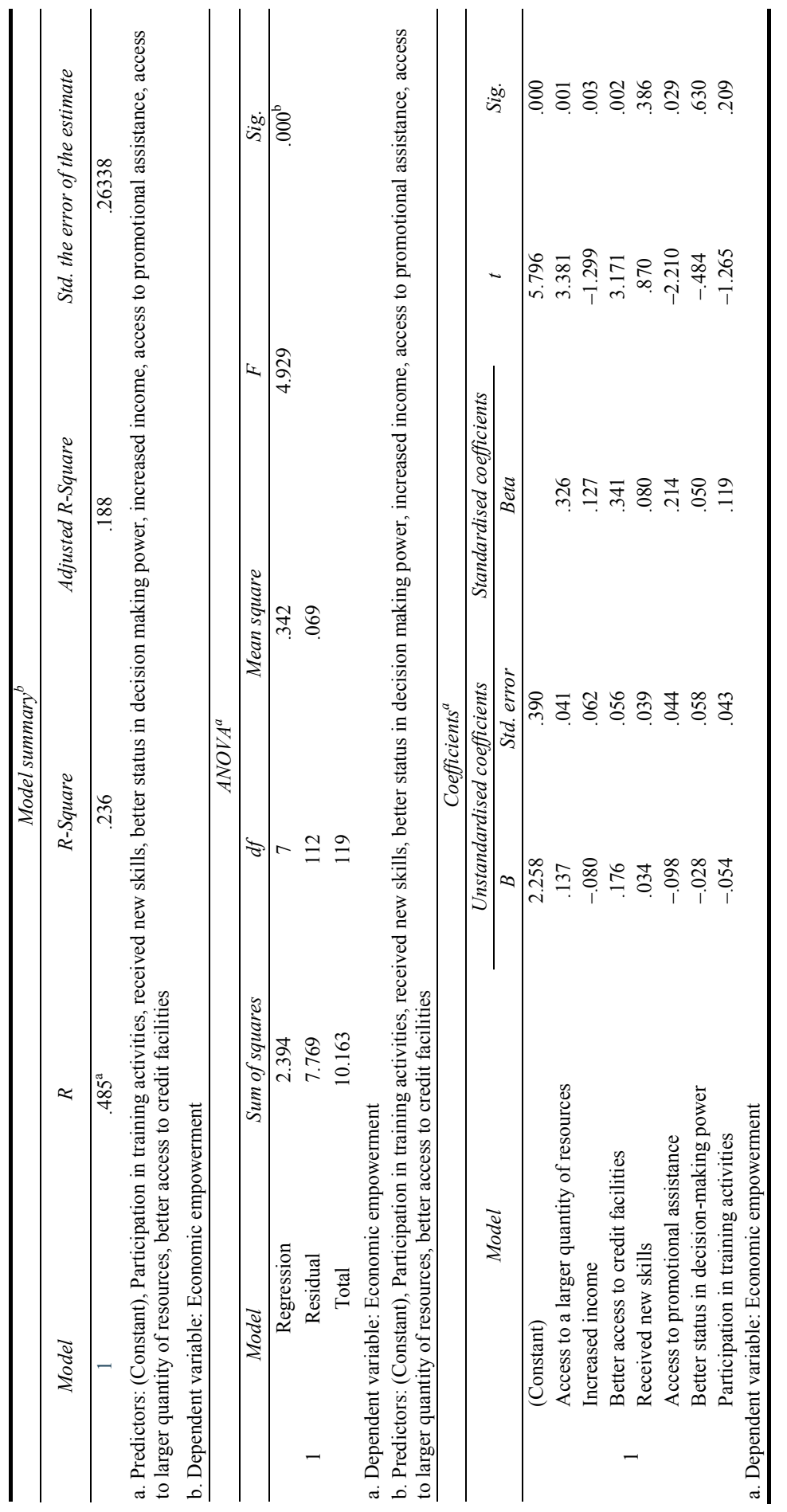




\section{Interpretation:}

Multiple regression analysis was conducted to determine the relationship between the participation in SHGBLP and Economic empowerment of members. This overall regression model produced an $R^{2}$ of .23 which means that the participation in SHGBLP explained $23 \%$ of the variance in the dependent variable Economic empowerment of members. The overall model was significant, $F(7,119)=4.929, p<.05$ and it accounted for $23 \%$ of the variance. It is found that better access to credit facilities $(\beta=.344$, $t=3.171, p=0.002$ ) has the highest significance or impact on economic empowerment of members followed by access to resources $(\beta=.326)$ and access to promotional assistance $(\beta=.214)$. Whereas, participation in training activities, new skills, and decision-making power are not having a significant impact on the Economic empowerment of members.

\section{Inference:}

Null hypothesis $H_{0}$ is rejected, Since $p(0.000)<0.005$, hence participation in SHGBLP has an impact on economic empowerment of SHG members.

Participation in SHGBLP showed a variance of $23 \%\left(R^{2}\right.$-value) on economic empowerment of members.

\section{$5 \quad$ Findings and discussion}

The study attempted to investigate the impact of participation in Stree Shakti program on the empowerment of women. Findings show a very strong positive influence on the social and economic empowerment of women participants.

Paired-t-test revealed that the members could increase their income considerably after participation in SHG under the Stree Shakti scheme due to the easy availability of credit and participation in income-generating activities, and also there is an increase in their expenditure after participation in SHG. It is noted that there has been no change in the savings of the members after participation in SHG. It shows that the credit available to them is used more for consumption purposes rather than for productive purposes. It is noted that the debt level of members has reduced significantly after participation in SHGBLP which shows that members are able to pay off their debts and are becoming self-sufficient.

Regression analysis revealed that awareness level has an impact on the social empowerment of women participants. By virtue of participation in the program the awareness level of the members has improved. It is found that social and legal awareness has the highest significance or impact on social empowerment of members followed by awareness about banking facilities and transaction and awareness about Govt. programs and schemes. The increased awareness in these areas is facilitating members to make better decisions and making them self-confident.

The study shows that participation in SHGBLP has a strong impact on the economic empowerment of women participants. It is found that better access to credit facilities has the highest significance or impact on the economic empowerment of members followed by access to resources and access to promotional assistance. Participation in the program has enabled members to have better access to credit facilities as SHG facilitates internal 
lending among members. The linkage with banks has facilitated members to get better access to resources and take part in promotional activities, which is helping them for sustained growth.

The research concludes by mentioning that participation in SHGBLP has impacted the social and economic empowerment of women. The study revealed that awareness level has caused a variance of $16 \%$ on Social empowerment of members, and participation in SHGBLP has caused a variance of $23 \%$ on the economic empowerment of members. SHGBLP has been instrumental in empowering members socially and economically.

\section{Conclusion}

The role of microfinance through the Stree Shakti program in empowering women is laudable. It is observed that educated middle-aged women show a keen interest in joining SHGs. The crucial motive behind joining is to increase their income level and elevate their economic status and the urge to save money for future use. It is remarkable to note that members have expressed good improvement in their income level, and also in their economic status. Stree Shakti program has impacted higher psychological and social empowerment along with economic empowerment. If we look at indicator of economic empowerment the program has a strong impact on the economic empowerment of women which concurs with the previous study by Hundekar (2019). Further, the impact is significant in bringing confidence, leadership, skill development in rural areas, particularly in women. To conclude, participation in Stree Shakti program has led to an enhancement in awareness level, psychological wellbeing, and socio-economic empowerment among rural women. Thus, it can be stated that SHG-Bank Linkage is a strategic tool to achieve women empowerment among the rural women flock. Hence, microfinance is considered to be an effective financial intermediary for empowering women and socio-economic upliftment. If microfinance initiatives are channelised effectively it is instrumental in generating employment and savings.

\section{$7 \quad$ Implications of the study}

From the policy perspective, this study proves to be helpful in measuring the success and reach of SHGBLP, degree of financial exclusion, inequality, income disparity and regional variation in financial inclusion. The study provides a panoramic view of the role of SHGBLP in the empowerment of rural women and its role in the overall financial inclusion of the economy.

\section{Scope for future research}

- The efficiency of different SHGs could be analysed based on geography, and types of business done.

- The research may be further expanded to a comparative study of the status of this microfinance activity with various states vis-à-vis Karnataka. 
- Research can be carried out on urban SHGs and comparisons can be made between the two

- Further research can be conducted on the segment of the population who are availing SHG loans through the bank linkage program. The region-wise study can be undertaken to know the success of the reach of this initiative in different regions, and the level of awareness among rural people about the policy initiative can be assessed.

\section{References}

Bammi, R. (2014) 'SHG bank linkage: lending a helping hand?', Vision: the journal of Business perspective (09722629), Vol. 18, No. 3, pp.237-244.

Brody, C., Hoop, T., de Vojtkova, M., Warnock, R., Dunbar, M., Murthy, P. and Dworkin, S.L. (2017) 'Can self-help group programs improve women's empowerment? A systematic review', Journal of Development Effectiveness, Vol. 9, No. 1, pp.15-40.

Census of India (2019) Census of India 2011. Available online at: https://www.censusindia2011.com/karnataka-population.html (accessed on June 2019).

Das, S. and Bhowal, A. (2013) 'Self-help groups - an empowerment model or financial model: perceptions of stakeholders', European Journal of Business and Management, pp.170-190.

Das, T. and Guha, P. (2019) 'Measuring women's self-help group sustainability: a study of rural Assam', International Journal of Rural Management, Vol. 15, No. 1, pp.116-136.

Datta, U. (2015) 'Socio-economic impacts of JEEViKA: a large-scale self-help group project in Bihar, India', World Development, Vol. 68, pp.1-1.

Desai, R.M. and Olofsgård, A. (2019) 'Can the poor organize? Public goods and self-help groups in rural India', World Development, Vol. 121, pp.33-52.

District Wise Report on SHG Group (2018) Panchatantra. Available online at: http://www.panchatantra.kar.nic.in/STAT/shgstat (accessed in 2018).

Duflo, E. (2012) 'Women's empowerment and economic development', Journal of Economic Literature, pp.1051-1079.

Gangadhar, S.C.H. and Malyadri, P. (2015) 'Impact of microfinance on women empowerment: an empirical evidence from Andhra Pradesh', Journal of Entrepreneurship and Organization Management, pp.1-8.

Hundekar, V.R. (2019) 'An empirical study on Financial Inclusion through Self Help Groups Bank Linkage Programme - An Economic Catalyst to Transform Rural India', Proceedings of the 9th Annual International Conference on 4C's-Communication, Commerce, Connectivity, Culture, Pune, India.

Kumar, N., Raghunathan, K., Arrieta, A., Jilani, A.H., Chakrabarti, S., Menon, P. and Quisumbing, A.R. (2019) 'Social networks, mobility, and political participation: the potential for women's self-help groups to improve access and use of public entitlement schemes in India', World Development, Vol. 114, pp.28-41.

Mohan, K. (2011) Role of microfinance in women's empowerment (an empirical study in Pondicherry region rural SHG's)', Journal of Management and Science, pp.1-8.

Mohapatra, S. and Sahoo, B. (2016) 'Determinants of participation in self-help-groups (SHG) and its impact on women empowerment', Indian Growth and Development Review, Vol. 9, No. 1, pp.53-78.

NABARD Report (2019) SHG Bank linkage program as the ultimate inclusion program. Available online at: https://www.nabard.org/auth/writereaddata/WhatsNew/1107171727Approved Final_Press_Release

Naganagoud, S.P. (2012) 'Microfinance and women empowerment: a study of Stree Shakti programmes in Bellary district of Karnataka', Public Policy and Administration Research, Vol. 1, No. 2, pp.11-18. 
Patil, S. and Kokate, K. (2017) 'Identifying factors governing attitude of rural women towards self-help groups using principal component analysis', Journal of Rural Studies, Vol. 55, pp.157-167.

Pillai, D. and Abraham, S. (2017) 'Mediating role of self-help groups for stimulating rural financial intermediation in India', Journal of Internet Banking and Commerce, Vol. 22, pp.1-11.

Poominathan, S., Amilan, S. and Muthukrishnan, B. (2016) 'Impact of microfinance on women empowerment through self-help groups', Pacific Business Review International, Vol. 8, No. 10, pp.28-34.

Rajeev, M., Vani, B.P. and Veerashekharappa (2019) 'Group lending through an SHG banklinkage programme in India: transaction costs and social benefits', Development in Practice, Vol. 30, No. 2, pp.161-181.

Sandhya, P.S. and Ranjini, S. (2018) 'Impact of microfinance through self-help groups: a study on the economic status of urban women working in production manufacturing sectors in Mysuru District', International Journal of Mechanical Engineering and Technology (IJMET), pp.472-481.

Sarania, R. (2015) 'Impact of self-help groups on economic empowerment of women in Assam', International Research Journal of Interdisciplinary \& Multidisciplinary Studies, pp.148-159.

Swamy, V. (2014) 'Financial inclusion, gender dimension, and economic impact on poor households', World Development, Vol. 56, pp.1-15. Doi: 10.1016/j.worlddev.2013.10.019.

Thangamani, S. and Muthuselvi, S. (2013) 'A study on women empowerment through self-help groups with special reference to Mettupalayam Taluk in Coimbatore District', Journal of Business and Management (IOSR-JBM), Vol. 8, No. 6, pp.17-24.

Vachya, L. and Kamaiah, B. (2015) 'Microfinance impact on socio-economic empowerment: a special reference to Andhra Pradesh', International Journal of Finance and Banking Studies, Vol. 4, No. 1, pp.51-69.

Yatnall, C.S., Banaka, M.B. and Huggi, B.H. (2012) 'Stri shakti groups - a parallel force', Procedia - Social and Behavioral Sciences, pp.296-303. 